\title{
Notes on Vampyressa thyone (Chiroptera: Phyllostomidae): distribution, genetics and hypopigmentation
}

\author{
Giovani Hernández-Canchola ${ }^{1} \mathbb{D}$, Yire A. Gómez-Jiménez ${ }^{1}$, Iván Hernández-Chávez ${ }^{1}$, \\ Sara Carolina Lucero-Verdugo ${ }^{I} \&$ Livia León-Paniagua ${ }^{1 *(1)}$ \\ ${ }^{1}$ Universidad Nacional Autónoma de México, Facultad de Ciencias, Departamento de Biología Evolutiva, \\ Museo de Zoología, Av. Universidad 3000, 04510, Ciudad de Mexico, Mexico \\ *Corresponding author: Livia León-Paniagua,e-mail:llp@ciencias.unam.mx
}

HERNÁNDEZ-CANCHOLA, G., GÓMEZ-JIMÉNEZ, Y.A., HERNÁNDEZ-CHÁVEZ, I., LUCERO-VERDUGO, S.C., LEÓN-PANIAGUA, L. Notes on Vampyressa thyone Chiroptera: Phyllostomidae): distribution, genetics and hypopigmentation. Biota Neotropica. 19(2): e20180621. http://dx.doi.org/10.1590/1676-0611-BN-2018-0621

\begin{abstract}
The frugivorous bats of the genus Vampyressa include five neotropical species, and some of them are considered relatively rare and uncommonly encountered. The northernmost distribution of this genus is in Mexico where only one species, the monotypic Vampyressa thyone, is found. Here, we report the Northwesternmost record for this species, extending its distribution range to the state of Guerrero, Mexico. This record extends the limit of the species distribution by more than $153 \mathrm{~km}$. We also compared this specimens with other $V$. thyone, and using mitochondrial cytochrome- $b$ sequences we detected three geographic clades within the species. The new Mexican specimen represent the most divergent cytochrome- $b$ sequence within $V$. thyone. We recommend a taxonomic revision to validate the taxonomic status of the three groups detected within $V$. thyone, particularly the differentiated Mexican clade. Additionally, we report a case of hypopigmentation in another $V$. thyone collected in a mature tropical rainforest in Chiapas, Mexico.
\end{abstract}

Keywords: Mexico; Northern little yellow-eared bat; pigmentation disorder; range extension; Stenodermatinae.

\section{Notas sobre Vampyressa thyone (Chiroptera: Phyllostomidae): distribución, genética e hipopigmentación}

Resumen: Los murciélagos frugívoros del género Vampyressa agrupan a cinco especies neotropicales, algunas de ellas consideradas relativamente raras y poco comunes de encontrar. Este género alcanza su distribución más norteña en México en donde solo una especie monotípica, Vampyressa thyone, habita. Reportamos el registro al noroeste más alejado para esta especie, extendiendo su rango de distribución al estado de Guerrero, México. Este registro extiende el límite de distribución de la especie por más de $153 \mathrm{Km}$. También comparamos este espécimen con otros $V$. thyone, y utilizando secuencias mitocondriales de citocromo-b detectamos tres clados geográficos dentro de la especie. El nuevo espécimen mexicano representa la secuencia de citocromo-b más divergente dentro de $V$ thyone. Recomendamos una revisión taxonómica para validar el estatus taxonómico de los tres clados detectados dentro de $V$. thyone, y en particular para el clado mexicano más diferenciado. Adicionalmente, reportamos un caso de hipopigmentación en otro $V$. thyone colectado en una selva húmeda tropical en Chiapas, México.

Palabras clave: México, murciélago norteño de orejas amarillas, desorden de pigmentación, extensión de distribución; Stenodermatinae. 


\section{Introduction}

The yellow-eared bats of the genus Vampyressa Wagner, 1843 consist of five different species, two of them recently described (Burgin et al. 2018). These bats are considered primarily or exclusively frugivorous, though little is known of their feeding habitats or ecology (Tavares et al. 2014). The distribution of this genus includes the Neotropical region, from Argentina to Mexico (Lim et al. 2003). However, in Mexico only one species of the genus is found, the Northern little yellow-eared bat Vampyressa thyone Thomas, 1909.

Vampyressa thyone is a small bat with a tragus, entire base of the ear, and upper edges of the ears yellow; and tail membrane short (6 -7 $\mathrm{mm}$ ), edge lightly fringed at center (Reid 2009). This species roosts in leaves of trees and shrubs, and these bats are found in very wet habitats, such as streams in gallery forest (Téllez-Girón 2014). Vampyressa thyone is monotypic and is found in Bolivia, Brazil, Peru, Ecuador, Colombia, Venezuela, Guyana, French Guiana, Panama, Costa Rica, Nicaragua, Honduras, Belize, Guatemala and southern Mexico (Lim et al. 2003). The species has been reported only in the Mexican states of Campeche, Chiapas, and its northernmost records are located in the states of Veracruz and Oaxaca (Lim et al. 2003, Téllez-Girón 2014). It is not currently recognized in any threat category by Mexican authorities or the IUCN (SEMARNAT 2010, Tavares et al. 2015).

In Mexico and Central America it is uncommon (Reid 2009), and in Mexico it is considered rare and few individuals have been collected from only a few sites (Téllez-Girón 2014). Besides, the information related with the geographic range of $V$. thyone is still fragmented or incomplete, for example, new records available in biodiversity portals have not been included in IUCN maps (Tavares et al. 2015). It is for the foregoing that our goal was to update the knowledge about the distribution of $V$. thyone based on a new northwestern record and the available data of this species.

\section{Materials and Methods}

During a field expedition in Coacoyulichán, in the municipality of Cuautepec, Guerrero, Mexico (1647'40.3”N; 9855'59.9”W), at 418 meters above sea level (Figure 1) on April 16th 2014, when we used 3 mist nets $(6,6$, and 15 meters during one night) set at ground level in a riparian forest on the side of a rocky river, we trapped a specimen of $V$. thyone and other phyllostomid and mormoopid bats. Coacoyulichán has a mean annual precipitation of $5.09 \mathrm{~mm}$, a mean annual maximum temperature of $32.79{ }^{\circ} \mathrm{C}$ and a mean annual minimum temperature of $19.60^{\circ} \mathrm{C}(\mathrm{SMN} 2009)$.

We followed the recommendation and procedures proposed by the American Society of Mammalogists (Sikes et al. 2011), and we collected the specimen following Mexico's wildlife legislation (SEMARNAT SGPA/DGVS/08257). The specimen (field number GHC212) is deposited in the Mammal Collection of the Zoology Museum, UNAM (Facultad de Ciencias - Universidad Nacional Autónoma de México, Mexico City, Mexico, MZFC-M). We preserved the specimen as a skin with skeleton (MZFC-M 16012) (Figure 2A-B), and we preserved tissue samples (heart, liver, and kidney; TN 6214).

To corroborate the identification of this specimen and to compare with other $V$. thyone, we obtained external and cranial measurements of this specimen, and we also sequenced the mitochondrial gene cytochrome- $b$ ( $c y t-b, 1,140 \mathrm{bp}$ ) following the protocols used by Hernández-Canchola and León-Paniagua (2017), which is available at GenBank (Accession number MK409639). We also downloaded the sequences available of other $V$. thyone (AY157048 - AY157054, DQ312428 - DQ312431) and related species (Vampyressa pusilla: AY157046 - AY157047, DQ312428; Vampyressa melissa: DQ312426 - DQ312427, FJ154185; Mesophylla macconnelli: AY157035 - AY157035; Vampyriscus nymphaea: DQ312415 - DQ312418; Vampyriscus brocki: AY157043, DQ312419-DQ312421; Vampyriscus bidens: AY157044 - AY157045, AY157055, FJ154181; Ectophylla alba: AY157033). We selected the best scheme of partition and evolution model $\left(c y t-b_{[1]}=\mathrm{SYM}+\mathrm{I}+\Gamma\right.$; $c y t-b_{[2]}=\mathrm{HKY}+\mathrm{I} ; c y t-b_{[3]}=\mathrm{GTR}+\mathrm{I}$ ) in PARTITIONFINDER 2 (Lanfear et al. 2017), and in MrBayes 3.2.3 (Ronquist et al. 2012) we used 3 hot and 1 cold chains, in two independent runs of 10 million generations, sampling data every 1000 iterations. The final topology was obtained using a majority tree consensus and considering a burn-in of $10 \%$. We checked the convergence of our results and a good sampling (ESS > 200) in TrACER 1.6. In Mega 6 (Tamura et al. 2013) we calculated the genetic distances between species, using the Kimura 2-parameter model.

To analyze geographic records of $V$. thyone available in biodiversity portals on the web, we downloaded this information from VertNet (http://portal.vertnet.org), UNIBIO (http://unibio.unam.mx), and Remib (http://www.conabio.gob.mx/remib/doctos/remib_esp.html), accessed on March 21st, 2018. We also included the geographic information from other specimens measured in this work: Mexico: Chiapas; Zona Arqueológica Monumento Natural Yaxchilán [16 53'53.6”N; 9057'52.5”W] (MZFC-M 7102, 7108); Porción norte de la omega, Monumento Natural Yaxchilán [1653'52.8'N; 9058'25.1'W] (MZFC-M 7159); Campamento Arqueológico del INAH de Yaxchilán [1654'3.5”N; 9058'9.8”W] (MZFC-M 7187). Oaxaca; San Isidro, "La Gringa" [176'13”N; 947'21"W] (MZFC-M 7760); La Luz, carretera rumbo a Río Grande [166'36.4’’N; 97³5'41.35’'W] (MZFC-M 8651).

\section{Results}

Here, we report the new northwesternmost record of Vampyressa thyone and the first record in the Mexican state of Guerrero. The $V$. thyone reported here was an adult male with no scrotal testes, which was found with Artibeus jamaicensis, A. lituratus, Carollia subrufa, Dermanura phaeotis, Glossophaga commissarisi, G. leachii, G. soricina and Pteronotus parnellii.

In the genus Vampyressa there is a craniodental character, a small cusp in the lingual border of the longitudinal sulcus on posterior crown of upper canines (Tavares et al. 2014), but in the $V$. thyone specimens examined in the MZFC-M the accessory cusps seem to be more developed in males than in females. Nevertheless, in the new specimen the accessory cusp is even more developed than in the other males. This specimen in general also has the largest measurements of all measured specimens. External measurements, cranial measurements and weight of this specimen and all other $V$. thyone in the MZFC-M are shown in Table 1.

Our phylogenetic construction recovered the genera Vampyriscus, Mesophylla and Vampyressa as monophyletic. Besides, our results support that samples from Brazil and Paraguay recognized as Vampyressa pusilla, are an independent clade sister to Vampyressa thyone, which inhabits from Bolivia to Mexico. Nevertheless, we 


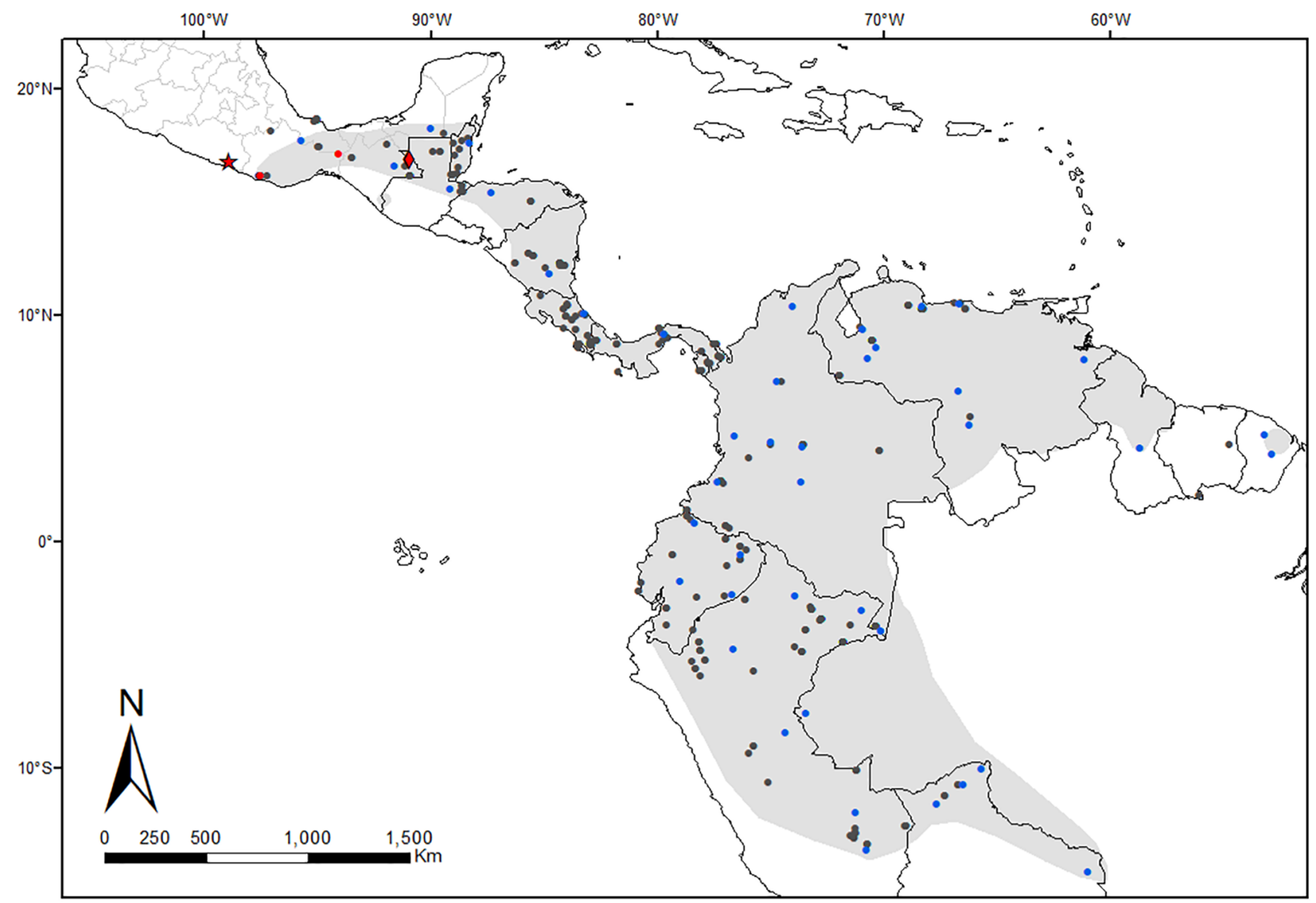

Figure 1. Geographic distribution of Vampyressa thyone. The gray area follows the geographic range from the IUCN Red List (Tavares et al. 2015). The blue dots are sites recorded by Lim et al. (2003) and Brosset and Charles-Dominique (1990), the gray dots are sites recorded in VertNet and UNIBIO, and the red symbols are specimens in the MZFC-M. The new Northwesternmost record is indicated with a star, and the hypopigmentation record with a diamond.

detected three genetic - geographic clades within $V$. thyone: a first clade with specimens from Peru to Panama, sister to a clade with specimens from Costa Rica to Honduras, and finally a third lineage, represented by the new Mexican record, sister to the two first clades (Figure 3). The genetic divergences ranged from $14.53-15.5 \%$ between $V$. thyone and the genus Vampyriscus, $13.21 \%$ with Mesophylla, $10.73 \%$ with Vampyressa melissa and $11.41 \%$ with Vampyressa pusilla. Within $V$. thyone the genetic distance between South and Central American clades was $2.1 \%$, and between the Mexican sample and South and Central American clades were 4.41 and $4.64 \%$, respectively.

In addition, there are records in VertNet and UNIBIO that have not been considered as marginal records of $V$. thyone by IUCN (Tavares et al. 2015): this species has been previously recorded in the Mexican states of Oaxaca and Veracruz; the specimen KU 143607 from Salado River, Oaxaca and specimens FMNH (127108-127111) and CNMA(TUX167 - TUX172, TUX315 - 322) from Sierra de los Tuxtlas, Veracruz, represent the northernmost records of this species. Furthermore, there are records from Suriname not previously considered by IUCN: specimens TTU 106030 and ROM 120356 (Figure 1). To include these records as part of $V$. thyone distribution is important to validate the identification of these specimens. We validated samples hosted in Mexican scientific collections (CNMA, MZFC-M), but we recommend the same for $V$. thyone hosted in USA (KU, FMNH, TTU, ROM).
During the review of specimens of $V$. thyone at the MZFC-M, we also detected an individual (MZFC-M 7108) (Figure 2C) with signals of hypopigmentation. The specimen is a female captured in the Zona Arqueológica Monumento Natural Yaxchilán, in the municipality of Ocosingo, Chiapas, Mexico (16 53 '53.6”N; 9057'52.5”W) that was collected on August 27th, 1998.

\section{Discussion}

The new specimen reported here represents the first record in the Mexican state of Guerrero, according to the most recent mammal checklist for the state (Espinosa-Martínez et al. 2017), the distribution of the samples used in the systematic revision of $V$. thyone (Lim et al. 2003) and in a previous range extension work (Brosset \& Charles-Dominique 1990). This specimen extends the northwestern limit of the species' distribution by more than $153 \mathrm{Km}$ and increases the bat diversity of Guerrero to 67 species. In Mexico, this state is considered one of the most diverse in terms of mammal species, despite reduced sampling effort by field researchers over the past 50 years due to social and security problems (Espinosa-Martínez et al. 2017). Increased sampling effort is necessary, mainly in Eastern Guerrero, because we suspect that other Stenodermatinae species with ecological requirements similar to $V$. thyone (such as Chiroderma villosum or Platyrrhinus helleri, which 
Hernández-Canchola, G. et al.
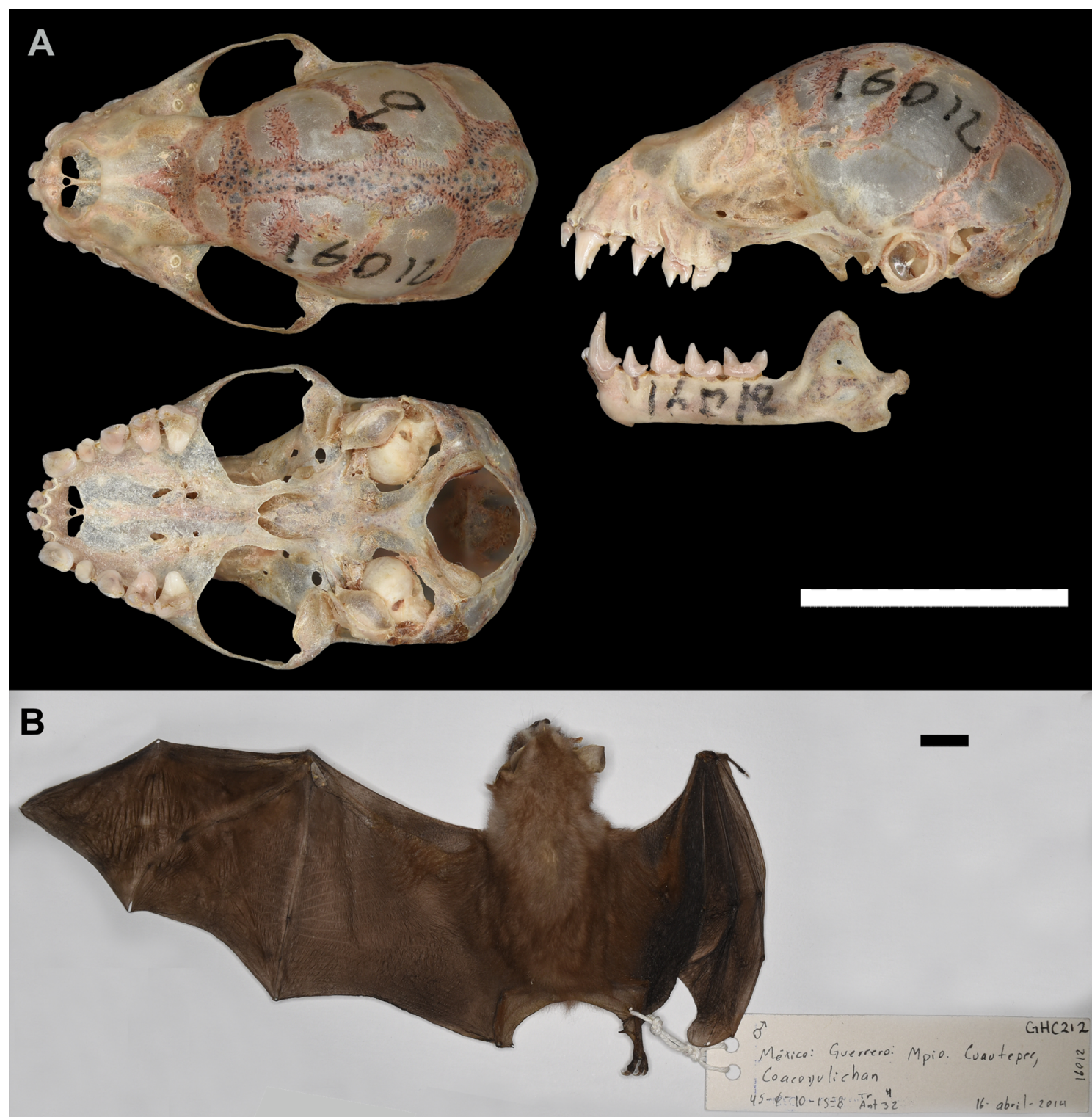

C

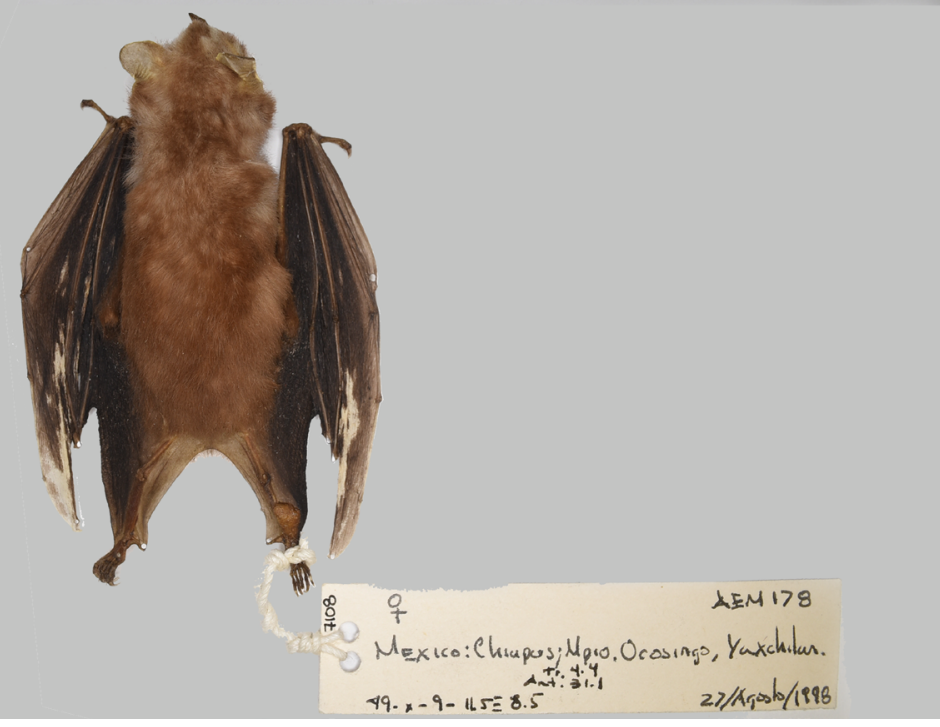

Figure 2. Vampyressa thyone reported in this study. The Northwesternmost specimen of $V$. thyone (MZFC-M 16012), from Coacoyulichán, Guerrero, Mexico: (A) Dorsal, ventral and lateral views of the skull and lateral view of the mandible (Scale bar $=1 \mathrm{~cm})$; (B) Dorsal view of skin $($ Scale bar $=1 \mathrm{~cm}) .(\mathrm{C}) \mathrm{The}$ hypopigmented specimen of $V$. thyone (MZFC-M 7108), from Zona Arqueológica Monumento Natural Yaxchilán, Chiapas, Mexico. The white spots are located on both wings. 
Table 1. Measurements (mm) and weight (g) of the Vampyressa thyone at the MZFC-M.

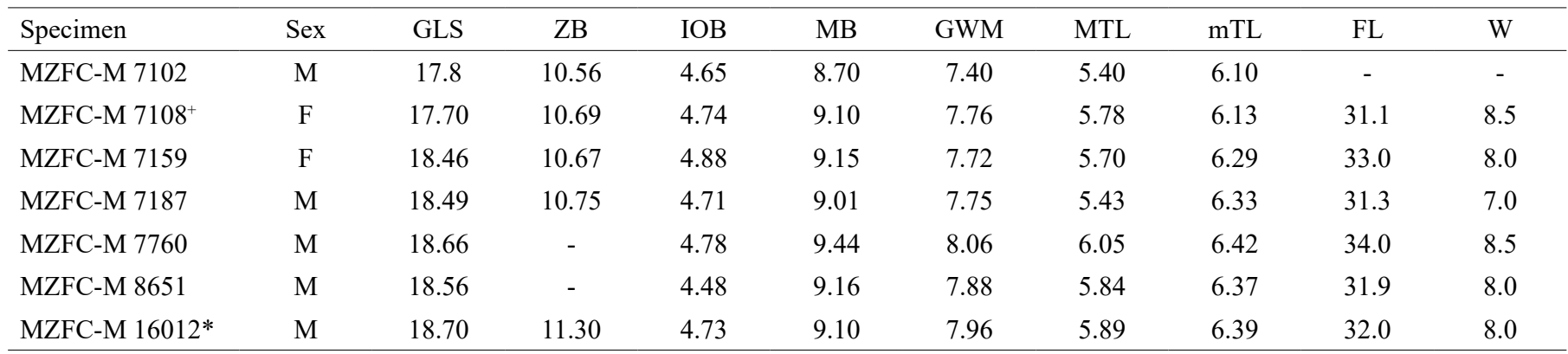

${ }^{+}$Hypopigmentation record and * New Northwesternmost record. GLS: greatest length of skull, ZB: zygomatic breadth, IOB: interorbital breadth, MB: mastoid breadth, GWM: greatest width across upper molars, MTL: maxillary toothrow length, mTL: mandibular toothrow length, FL: forearm length, and W: weight.

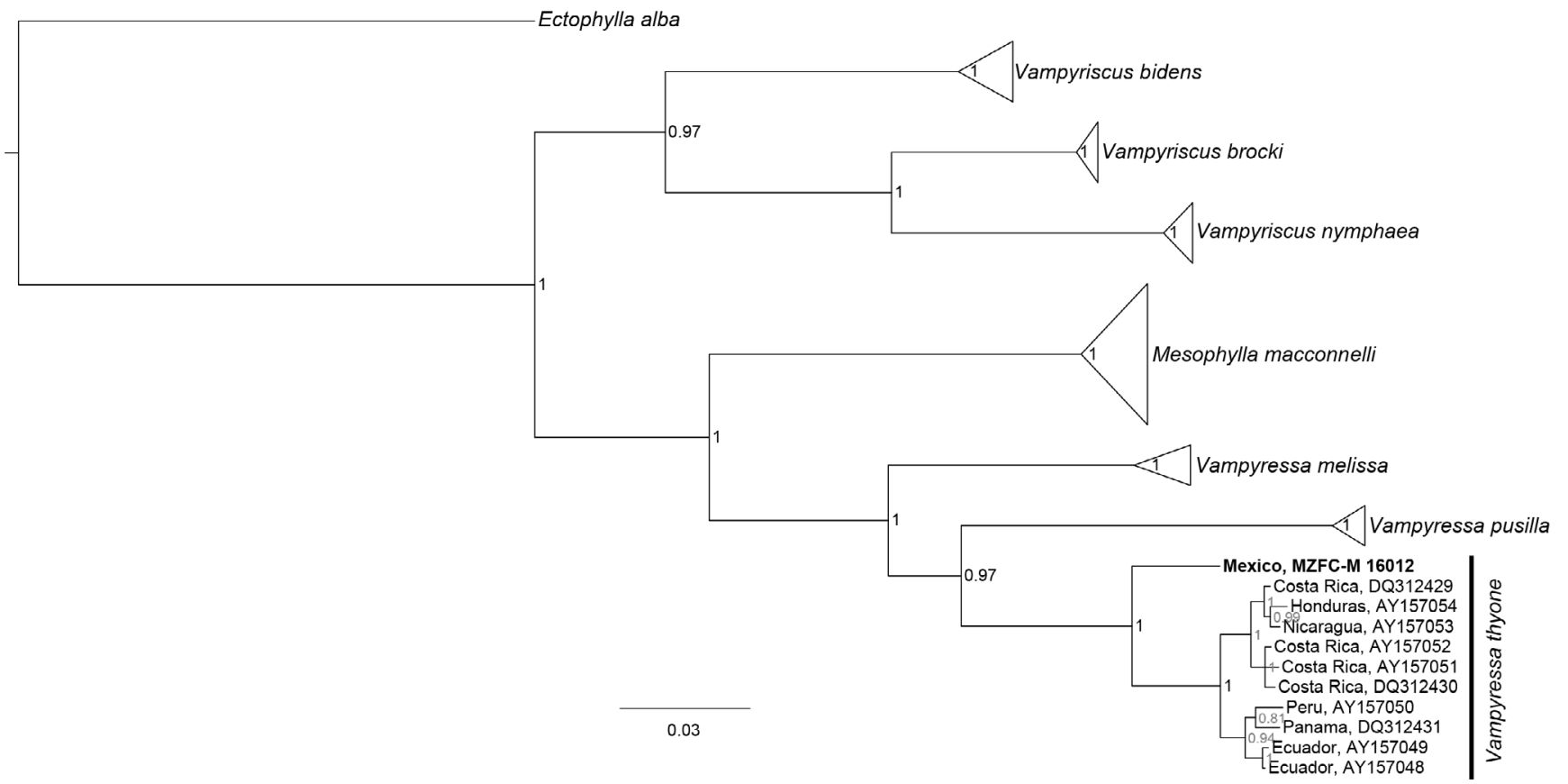

Figure 3. Topology obtained using a Bayesian inference that shows the phylogenetic relationships of $V$. thyone and related species. The height of enclosing triangles is proportional to the number of samples they contain, and the numbers at the nodes represent posterior probabilities.

have their limits until Oaxaca state; Pacheco R., 2014; Tellez-Giron, 2014), could inhabit Guerrero due to the continuity of habitats and absence of geographical barriers.

The topology of our Bayesian inference is similar to previous phylogenies (Porter \& Baker 2004, Hoofer \& Baker 2006), despite mixing both sets of data and including new sequences reported by Velazco \& Patterson (2008). On the other hand, the genetic clades with geographic agreement within $V$. thyone have been reported in other Stenodermatinae bats, such as the genus Platyrrhinus (Velazco \& Patterson 2008) and Sturnira (Hernández-Canchola \& León-Paniagua 2017), and in some cases those clades represent different species. Besides, the genetic distance of the new Mexican specimen is the highest within $V$. thyone, so we recommend an integrative taxonomic revision of the three groups detected, to properly define species boundaries.

The specimen with pigmentation disorder represents the first record of hypopigmentation in $V$. thyone, and this atypical coloration of the wings has been reported in many other Neotropical bats species (Zalapa et al. 2016, Lucati \& López-Baucells 2017). Nowadays there is no consensus about the classification of chromatic disorders, but according to recent proposals of chromatic disorders in bats, the category of hypopigmentation in this $V$. thyone represents a case of white spots (Zalapa et al. 2016) or piebaldism (Lucati \& López-Baucells 2017). Failures in pigmentation differentiation or deposition, or infectious diseases are possible causes of hypopigmentation (Rose et al. 2017), though the causes and consequences of this phenomenon in bats are still unclear (Zalapa et al. 2016). We agree with authors that suggest that survival is not affected by hypopigmentation, as the specimen we report was an adult when captured, and many other bats with hypopigmentation even show signs of reproduction (e.g. Sánchez-Hernández et al., 2012). Besides, this condition is a taxonomic character in the bat Diaemus youngi, and there is no evidence that it can be detrimental to survival and reproduction of the species (Greenhall \& Schut 1996). 
Vampyressa pusilla was described by Wagner (1843), and $V$. thyone was originally described as a species by Thomas (1909), but the holotype of $V$. pusilla is a sub-adult male. For that reason, Goodwin (1963) recommended that $V$. thyone be considered a subspecies of $V$. pusilla, because he suggested that characters that distinguish both entities were related to age rather than geographic variables (Lim et al. 2003). Later, the work of Lim et al. (2003) re-evaluated the systematic relationship between $V$. pusilla and $V$. thyone. Based on quantitative mensural data, quantitative morphological characters, chromosomal differences, and mitochondrial synapomorphies, they recognized $V$. thyone as an independent and valid species, and here we are increasing the limited knowledge about the natural history of the Northern little yellow-eared bat, $V$. thyone.

\section{Acknowledgments}

We are grateful to M. Laura Ruiz-Vega, Martin Y. Cabrera-Garrido and Alfredo A. Gutiérrez-González for support during fieldwork, and with Joaquín Arroyo-Cabrales and three reviewers for his comments and criticisms. We are also grateful to local community authorities of Coacoyulichán for allowing us to conduct fieldwork. The first author is grateful to CONACyT and Posgrado en Ciencias Biológicas - UNAM for scholarships. This work was founded by the project CONACyT 239482.

\section{Authors contribution}

Giovani Hernández-Canchola: Substantial contribution in the concept and design of the study; Contribution to data collection; Contribution to data analysis and interpretation; Contribution to manuscript preparation.

Yire A. Gómez-Jiménez: Substantial contribution in the concept and design of the study; Contribution to data collection; Contribution to manuscript preparation.

Iván Hernández-Chávez: Contribution to data collection; Contribution to manuscript preparation.

Sara Carolina Lucero-Verdugo: Contribution to manuscript preparation.

Livia León-Paniagua: Substantial contribution in the concept and design of the study; Contribution to manuscript preparation.

\section{Conflicts of interest}

The authors declare that they have no conflict of interest related to the publication of this manuscript.

\section{References}

BROSSET, A. \& CHARLES-DOMINIQUE, P. 1990. The bats from FrenchGuiana: a taxonomic, faunistic and ecological approach. Mammalia 54(4):509-560.

BURGIN, C.J., COLELLA, J.P., KAHN, P.L. \& UPHAM, N.S. 2018. How many species of mammals are there? J. Mammal. 99(1):1-14.
ESPINOSA-MARTÍNEZ, D. V., RÍOS-MUÑOZ, C.A., ROSALES NANDUCA, H., ARROYO-CABRALES, J. \& LEÓN-PANIAGUA, L. 2017. Mamíferos de Guerrero. Rev. Mex. Mastozoología Nueva época 7(2):38-67.

GOODWIN, G.G. 1963. American bats of the genus Vampyressa, with the description of a new species. Am. Museum Novit. 2125:1-24.

GREENHALL, A.M. \& SCHUT JR., W.A. 1996. Diaemus youngi. Mamm. Species 533:1-7.

HERNÁNDEZ-CANCHOLA, G. \& LEÓN-PANIAGUA, L. 2017. Genetic and ecological processes promoting early diversification in the lowland Mesoamerican bat Sturnira parvidens (Chiroptera: Phyllostomidae). Mol. Phylogenet. Evol. 114:334-345.

HOOFER, S.R. \& BAKER, R.J. 2006. Molecular systematics of Vampyressine bats (Phyllostomidae: Stenodermatinae) with comparison of direct and indirect surveys of mitochondrial DNA variation. Mol. Phylogenet. Evol. 39(2):424-438.

LANFEAR, R., FRANDSEN, P.B., WRIGHT,A.M., SENFELD, T. \& CALCOTT, B. 2017. PartitionFinder 2: new methods for selecting partitioned models of evolution for molecular and morphological phylogenetic analyses. Mol. Biol. Evol. 34(3): 772-773.

LIM, B.K., PEDRO, W.A. \& PASSOS, F.C. 2003. Differentiation and species status of the Neotropical yellow-eared bats Vampyressa pusilla and $V$. thyone (Phyllostomidae) with a molecular phylogeny and review of the genus. Acta Chiropterologica 5(1):15-29.

LUCATI, F. \& LÓPEZ-BAUCELLS, A. 2017. Chromatic disorders in bats: a review of pigmentation anomalies and the misuse of terms to describe them. Mamm. Rev. 47(2):112-123.

PACHECO R., J. 2014. Chiroderma villosum Peters, 1860. In Mammals of Mexico (G. Ceballos, ed.) Johns Hopkins University Press, Baltimore, Maryland, p.730-731.

PORTER, C.A. \& BAKER, R.J. 2004. Systematics of Vampyressa and related genera of phyllostomid bats as determined by cytochrome-b sequences. J. Mammal. 85(1):126-132.

REID, F.A. 2009. A field guide to the mammals of Central America and Southeast Mexico. Oxford University Press, New York, New York.

RONQUIST, F., TESLENKO, M., VAN DER MARK, P., AYRES, D.L., DARLING, A., HÖHNA, S., LARGET, B., LIU, L., SUCHARD, M.A. \& HUELSENBECK, J.P. 2012. Mrbayes 3.2: efficient bayesian phylogenetic inference and model choice across a large model space. Syst. Biol. 61(3):539-542

ROSE, A., BRÄNDEL, S.D., CVECKO, P., ENGLER, S., HILLER, T., KNÖRNSCHILD, M. \& TSCHAPKA, M. 2017. New records of hypopigmentation in two neotropical phyllostomid bat species with different roosting habits (Uroderma bilobatum, Glossophaga soricina). Mammalia 81(6):615-619.

SÁNCHEZ-HERNÁNDEZ, C., ROJAS-MARTÍNEZ, A.E., LÓPEZ-VIDAL, J.C., ELIZALDE-ARELLANO, C., ROMERO-ALMARAZ, M. de L., AGUILLAR-LÓPEZ, M. \& TABOADA-SALGADO, A. 2012. Leucism in five species of bats from Mexico. Chiropt. Neotrop. 18(2):1123-1127.

SEMARNAT. 2010. Norma Oficial Mexicana NOM-059-SEMARNAT-2010, Protección ambiental-Especies nativas de México de flora y fauna silvestresCategorías de riesgo y especificaciones para su inclusión, exclusión o cambio-Lista de especies en riesgo. D. Of. la Fed. 30 diciemb1-78.

SIKES, R.S., GANNON, W.L. \& THE ANIMAL CARE AND USE COMMITTEE OF THE AMERICAN SOCIETY OF MAMMALOGIST. 2011. Guidelines of the American Society of Mammalogists for the use of wild mammals in research. J. Mammal. 92(1):235-253.

SMN. 2009. Información climatológica por estado: Guerrero, Coacoyulichan, Cuautepec. http://smn.cna.gob.mx/es/informacion-climatologica-verestado?estado=gro Acceced on 26 March 2018. 
TAMURA, K., STECHER, G., PETERSON, D., FILIPSKI, A. \& KUMAR, S. 2013. MEGA6: Molecular evolutionary genetics analysis version 6.0. Mol. Biol. Evol. 30(12):2725-2729.

TAVARES, V. da C., GARDNER, A.L., RAMÍREZ-CHAVES, H.E. \& VELAZCO, P.M. 2014. Systematics of Vampyressa melissa Thomas, 1926 (Chiroptera: Phyllostomidae), with descriptions of two new species of Vampyressa. Am. Museum Novit. 3813:1-27.

TAVARES, V. da C., MUÑOZ, A. \& ARROYO-CABRALES, J. 2015. Vampyressa thyone. The IUCN red list of threatened species 2015: e.T136671A21989318. http://dx.doi.org/10.2305/IUCN.UK.2015-4.RLTS. T136671A21989318.en. Acceced on 04 April 2018.
TELLEZ-GIRON, G. 2014. Platyrrhinus helleri (Peters, 1866). In Mammals of Mexico (G. Ceballos, ed.) Johns Hopkins University Press, Baltimore, Maryland, p.736-737.

TÉLLEZ-GIRÓN, G. 2014. Vampyressa thyone Thomas, 1909. In Mammals of Mexico (G. Ceballos, ed.) Johns Hopkins University Press, Baltimore, Maryland.

VELAZCO, P.M. \& PATTERSON, B.D. 2008. Phylogenetics and biogeography of the broad-nosed bats, genus Platyrrhinus (Chiroptera: Phyllostomidae) Mol. Phylogenet. Evol. 49(3):749-759.

ZALAPA, S.S., GUERRERO, S., ROMERO-ALMARAZ, M. de L. \& SÁNCHEZ-HERNÁNDEZ, C. 2016. Coloración atípica en murciélagos: frecuencia y fenotipos en Norte y Centroamérica e islas del Caribe y nuevos casos para México y Costa Rica. Rev. Mex. Biodivers. 87:474-482.

Received: 02/08/2018

Revised: 17/01/2019

Accepted: 11/02/2019

Published online: 25/02/2019 